following the approximate rule. It will be seen that for angles less than $15^{\circ}$ this error is always less than one degree.

\begin{tabular}{|c|c|c|c|c|}
\hline & $(1)$ & $(2)$ & $(3)$ & $(4)$ \\
\cline { 2 - 4 } & 1 in & 1 in & & \\
\hline $1^{\circ}$ & $57 \cdot 29$ & 60 & $58^{\prime}$ & $2^{\prime}$ \\
$2^{\circ}$ & $28 \cdot 64$ & 30 & $1^{\circ} 55^{\prime}$ & $5^{\prime}$ \\
$3^{\circ}$ & $19 \cdot 08$ & 20 & $2^{\circ} 52^{\prime}$ & $8^{\prime}$ \\
$4^{\circ}$ & $14 \cdot 30$ & 15 & $3^{\circ} 49^{\prime}$ & $11^{\prime}$ \\
$5^{\circ}$ & $11 \cdot 43$ & 12 & $4^{\circ} 46^{\prime}$ & $18^{\prime}$ \\
$10^{\circ}$ & $5 \cdot 67$ & 6 & $9^{\prime} 27^{\prime}$ & $33^{\prime}$ \\
$15^{\circ}$ & $3 \cdot 73$ & 4 & $14^{\circ} 2^{\prime}$ & $58^{\prime}$ \\
$20^{\circ}$ & $2 \cdot 75$ & 3 & $18^{\prime} 26^{\prime}$ & $1^{\circ} 34^{\prime}$ \\
$25^{\circ}$ & $2 \cdot 14$ & $2 \cdot 4$ & $22^{\circ} 37^{\prime}$ & $2^{\circ} 23^{\prime}$ \\
$30^{\circ}$ & $1 \cdot 73$ & 2 & $26^{\circ} 33^{\prime}$ & $3^{\circ} 27^{\prime}$ \\
$35^{\circ}$ & $1 \cdot 43$ & & & \\
$40^{\circ}$ & $1 \cdot 19$ & & & \\
$45^{\circ}$ & 1 & & & \\
\hline
\end{tabular}

Explanation. $-3^{\circ}$ is actually 1 in 19.08 ; the approximate rule gives it 1 in $20 ; 1$ in 20 is $2^{\circ} 52^{\circ}$; error from following approximate rule $8^{\prime}$.

In Fig. 1 the dip along $A B$ is $4^{\circ}$ or 1 in $14 \cdot 30$, the dip along $A C$ is $15^{\circ}$ or 1 in $3 \cdot 73: A B=1430, A C=373$, dropping the decimals. $A D$ is found to be 290 . Hence the full dip is 1 in 2.9 or $19^{\circ}$ very nearly.

A. H. Green.

LeEDS, July 13, 1876.

MR. MILNE ON FLOATING ICE.

Sir,-When comparing the altitude of an iceberg above water with the depth immersed, Mr. Milne has not sufficiently considered the conditions of stable equilibrum. A berg of the shape figured on page 307 could not remain in that position, but must turn over. That this would be the case may be seen by placing a boxwood tetrahedron (out of a set of models of crystals) in water, where it will float only with one of its angles downwards.

The position of stable equilibrium depends on the shape of the floating body, and on its specific gravity. The specific gravity of boxwood being about 0.95 , is so nearly the same as that of ice, that the positions assumed by a floating mass of either substance will as a rule be almost identical.

O. Fisher.

\title{
THE OLDEST FOSSILIFEROUS ROCKS OF NORTHERN EUROPE.
}

Sir,-The evidence brought forward by Prof. Linnarsson in the June Number of the Geological Magazine, as being opposed to the views advanced by me, has been already disposed of to a great extent in the papers in which these views have been propounded. ${ }^{1}$ That Prof. Linnarsson is unable to put forward stronger evidence in opposition to these views, is clearly a powerful argument in my favour, and I doubt whether he would have raised the objection at all had

${ }^{1}$ Quart. Journ. Geol. Soc. vol. zxxi. p. 552 seq.; Gzor. MAG. Dec. II. Vol. III. Nos. IV. V. VI. is 